The Ancient Burial-Mounds of England

By L. V. Grinsell. Pp. xiii $+240+24$ plates. (London : Methuen and Co., Ltd., 1936.) 12s. 6d. net.

Mr. Grnnsell is an enthusiast about his subject; and although he does not profess to be a scientifically trained archæologist, if he fails to inspire the reader with his own enthusiasm, it will not be the fault of his excellent descriptions of the barrows of England. $\mathrm{He}$ includes all that the amateur will desire to know of the history of the study of barrows, of their types and chronology, of burial customs, of their folk-lore and of their local names. He describes the methods of study in field-work and by excavation. Finally, he gives a detailed topographical list of these monuments, of which the only criticism to be made is that it is more complete for the south of England than it is for the north. The illustrations are good, though small. Brief bibliographies are given for the benefit of those who wish to carry their studies further.

\section{Handbuch der biologischen Arbeitsmethoden}

Herausgegeben von Prof. Dr. Emil Abderhalden. Lief. 460. Abt. V: Methoden zum Studium der Funktionen der einzelnen Organe des tierischen Organismus, Teil 10, Heft 6. Allgemeine und vergleichende Physiologie. Eine Verstärkeranordnung zur Registrierung gehirnelektrischer Spannungen, von Rudolf Ottenthal; Neue kataphoretische Verfahren, von Hugo Theorell; Lichtelektrische Zellen und ihre Anwendung für wissenschaftliche Messungen, von Marie Wreschner. Pp. 1075-1234. (Berlin und Wien: Urban und Schwarzenberg, 1936.) 9 gold marks.

THE first paper describes an amplifier designed to work an oscillograph for recording electrical changes in the intact brain. The arrangement consists of a three-stage resistance capacity amplifier containing two pentode valves followed by a triode. The values of the various condensers and resistances are chosen to give a long time-constant, and the author claims an undistorted amplification of 70,500, constant over a frequency range of $10-500$ cycles per second.

An interesting application is described in which two amplifiers are simultaneously led off from the same cranial electrodes, thereby giving two oscillograms on the same photographic paper. One instrument responds normally over the complete frequency range, while the other, by means of large capacity condensers arranged in parallel with the anode resistances of the first two stages, amplifies efficiently only at frequencies of 1-10 cycles per second. From the two simultaneous oscillograms an approximate curve analysis is obtained.

The second paper describes an improved type of kataphoresis apparatus in which it is possible to maintain the solution at a constant $p \mathrm{H}$ value. Several examples of its application for the investigation of biochemical material are quoted, such as references to work on flavin, Warburg's respiratory co-enzyme, cytochrome $c$, blood serum, and the anti-pernicious anæmia principle of liver.

In a larger type of apparatus suitable for the purifica- tion of various substances, the cell has a greater cross. sectional area, and parchment paper diaphragms are employed to separate the intermediate buffer solutions.

The third paper commences with a fairly comprehensive survey of present-day knowledge of photoelectric phenomena, and includes a number of useful references. This section is followed by detailed descriptions of different types of photo-electric cells and their characteristics. The remainder of the paper is devoted to descriptions of numerous applications including microphotometry, spectrophotometry, colorimetry, nephelometry, pyrometry and polarimetry.

Die mathematischen Hilfsmittel des Physikers:

Von Prof. Dr. Erwin Madelung. Unter Mitarbeit von Dr. Karl Boehle und Dr. Siegfried Flügge. (Die Grundlehren der mathematischen Wissenschaften in Einzeldarstellungen, herausgegeben von R. Courant, Band 4.) Dritte vermehrte und verbesserte Auflage. Pp. xiii +381 . (Berlin : Julius Springer, 1936.) 28.80 gold marks.

THIs book falls into two distinct parts : mathematics and physics. The third edition differs from the second (published about twelve years ago) in respect of a more systematic handling of the subjects, the introduction of much new matter, including a chapter on group theory, and a complete rewriting of the chapter on quantum theory. The author's object is to provide for physicists a précis of those parts of mathematics which shall be of direct use, and which could only be otherwise obtained by consulting a large variety of text-books. In the second part of the book the equations of mathematical physics are formulated.

The result is excellent as a piece of clever con densation, but one cannot help feeling that to make any adequate use of matter in such concise formpractically no proofs or illustrations are given-the reader will have to consult the text-book after all. For the mathematician or physicist, however, the work affords admirable and useful summaries in their respective subjects.

\section{Faithful Rebels}

a Study in Jewish Speculative Thought. By Dr. Israel Levine. Pp. viii +146. (London; The Soncino Press, 1936.) 6s. net.

IN this work Dr. Israel Levine, the head of the Philosophy Department, University College, Exeter, discusses the outstanding contributions to philosophy by Jewish thinkers from biblical times down to the present day. In the oldest writings of Hebrew culture as represented by the Book of Job and Ecclesiastes and the works of Philo and Maimonides, little philosophy is to be found, and it is not until the middle of the seventeenth century that Jewish philosophy begins with Spinoza, while in the nineteenth and present centuries Marx represents economic science and Bergson metaphysics. Dr. Levine comes to the conclusion that science and philosophy are not really native to the Hebrew genius, but require for their development the stimulus of alien culture and the raw material of alien contact. 